Co-Evolutionary Urban Planning of a Finnish City for its Low-Growth Neighborhoods

Hanna Kosunen ${ }^{\mathrm{a} *}$, Irina Atkova ${ }^{\mathrm{b}}$ and Sari Hirvonen-Kantola ${ }^{\mathrm{a}}$

${ }^{a}$ Oulu School of Architecture, University of Oulu, Oulu, Finland; ${ }^{b}$ Oulu Business

School, University of Oulu, Oulu, Finland

*corresponding author Hanna Kosunen, hanna.kosunen@oulu.fi

This is an Accepted Manuscript of an article published by Taylor \& Francis in Planning

Theory \& Practice on 24 August 2020, available at:

https://doi.org/10.1080/14649357.2020.1806342 


\title{
Co-Evolutionary Urban Planning of a Finnish City for its Low-Growth Neighborhoods
}

\author{
Mainstream urban planning relies on economic growth to produce social and \\ environmental benefits, but in low-growth areas that relationship is not \\ functional. We argue that urban planning in low-growth areas could reveal new \\ ways to produce welfare by taking action without pre-defining the outcomes. We \\ define such planning as co-evolutionary, and study how urban planners in the \\ City of Turku, Finland, applied it in three low-growth contexts. We conclude that \\ the approach was recognized, but taking action under conditions of uncertainty \\ was challenging. Further, we identify three activities and challenges related to co- \\ evolutionary urban planning in low-growth areas.
}

Keywords: Co-evolutionary planning, low growth, proactiveness, urban development, organizational ecocycle

\section{Introduction}

Urban planning often relies on economic growth to bring about urban development. This casts doubt on its capacity to function in low-growth areas, defined as those with limited prospects for population growth and low demand for market-led urban development (Janssen-Jansen et al., 2012; Rydin, 2013). Cities have, in their master plans, designated urban development to selected locations, which has guided the formation of sustainable urban structures and provided certainty for the markets (Janssen-Jansen et al., 2012). Further, cities have used market-based urban development projects to generate benefits for the wider community by negotiating these with project developers (Rydin, 2013). However, in areas with no market demand for new land uses, the model is not functioning, as private developers show no interest in the development opportunity (Janssen-Jansen et al., 2012; Rydin, 2013). In addition, since development prospects in low-growth contexts are uncertain, planning intended to linearly program 
urban development has been criticized (De Roo \& Boelens, 2016; Janssen-Jansen et al., 2012). The limitations of growth-dependent planning have become tangible in largescale development projects halted due to economic crises (Savini et al., 2014) and in shrinking areas (Schlappa \& Neill, 2013), where conservation of past opportunities has hindered adaptation to the new situation. However, low-growth areas might be neglected in this discussion, as there are neither ongoing urban development projects nor acute crises that would draw attention to them. This entails the risk of dysfunctional urban structures and social inequality, if areas with fewer resources go unnoticed in urban policy-making (see Savini et al., 2014). Further, neglecting low-growth areas might threaten environmental sustainability, if the resources bound to the built environment remain underutilized (Rydin, 2013).

Viewing urban planning from the governance perspective, where urban development is planned and implemented through cooperation between government, private sector and civil society actors, offers insights into urban planning in low-growth contexts. While ideally all stakeholders would have an equal opportunity to affect outcomes, market actors often have the necessary resources to advance urban development, and therefore a strong position in governance networks (Rydin, 2013). Consequently, urban planning is characterized by dependence on economic growth, even though the relation is not functional in all situations (Rydin, 2013). Janssen-Jansen et al. (2012) suggest that under increasing economic uncertainty, cities must consider where alternative urban development models, such as those focusing on the maintenance of the existing built environment, are needed. In terms of governance, urban development in low-growth contexts could be initiated by cities and local communities (Janssen-Jansen et al., 2012; Rydin, 2013; Schlappa \& Neill, 2013). The logic of this model is different to that of growth-dependent planning: it might not bring 
monetary profit but might deliver values that directly benefit the neighborhood, such as improved everyday life (Rydin, 2013; Schlappa \& Neill, 2013). The development is also based on available resources, rather than building on growth expectations (Rydin, 2013; Schlappa \& Neill, 2013).

This discussion emphasizes the role of present actors and resources in urban development, putting the focus on what already exists. However, as urban planning by definition aims to change the current situation into one that is more desirable, it also entails drawing conclusions about what could be (Campbell, 2012). The challenge in low-growth contexts is that the envisioned future should be realistic when viewed from the present, constrained situation (Schlappa \& Neill, 2013). One approach could be to gradually generate urban change by proactively affecting urban development and adapting to the outcomes in a co-evolutionary fashion. Indeed, in today's uncertain and complex urban development contexts, urban planning increasingly requires the ability to simultaneously advance and adapt to urban change (De Roo \& Boelens, 2016; Ferreira et al., 2020; Savini et al., 2014). However, the resulting uncertainty is often discomforting: planning is expected to produce clearly defined problems and solutions, and the mere exploration of opportunities is considered insufficient (Beunen et al., 2016). Moreover, in constrained contexts, it might be challenging to decide what proactive action to take (Schlappa \& Neill, 2013; Forester, 2016). Yet, research on coevolutionary planning has mostly focused on large-scale development projects facing contextual volatility (see for example Bertolini, 2010; Gerrits \& Teisman, 2012; Majoor, 2015), whereas to our knowledge few studies (see Boelens \& Coppens, 2015; Schlappa \& Neill, 2013) have dealt with contexts whose starting point is a constrained situation. 
Our aim is to explore how co-evolutionary urban planning can be applied to low-growth contexts. In the following, we introduce co-evolutionary planning (Bertolini, 2007, 2010; Gerrits \& Teisman, 2012; Van Assche et al., 2017) and its potential application in low-growth contexts (Schlappa, 2016; Schlappa \& Neill, 2013), building on the concept of the organizational ecocycle (Hurst, 1995, 2012; Hurst \& Zimmerman, 1994) and the associated mode of rational action, which we identify as compatible with co-evolutionary planning. We then identify this action mode from our empirical material, three low-growth urban development cases in the suburbs of the city of Turku, Finland. We conclude by suggesting three planning activities for low-growth areas and discussing three challenges that may hinder their application.

\section{Co-Evolutionary Urban Planning}

The notion of co-evolution originates from ecology but is increasingly applied to social sciences, including urban planning (Boelens \& De Roo, 2016). Scholars who view cities as complex adaptive systems propose co-evolutionary planning as a planning strategy suitable for dealing with unpredictability (Boelens \& De Roo, 2016; De Roo, 2012). While co-evolutionary planning influences its context by proposing targeted actions, it also adapts to contextual changes (Bertolini, 2010). It starts with adaptation, by viewing urban development as path dependent, and considering how history and context influence possibilities to act (Bertolini, 2007; Van Assche et al., 2017). Deliberate actions resulting from planning may further rule out some development trajectories while reinforcing others (Gerrits \& Teisman, 2012). However, co-evolutionary planning adapts to emerging developments, and thereby acknowledges that urban development does not always follow the trajectory that was originally intended (Bertolini, 2007; Gerrits \& Teisman, 2012). 
Co-evolutionary planning thus combines adaptiveness and proactiveness. Here we define adaptiveness as adjustment to contextual changes (Boelens \& De Roo, 2016). In co-evolutionary planning, adaptation is a positive feature that acknowledges transformation and change, in contrast to linear planning that fails to consider these dynamics (see Davoudi, 2012). Yet, co-evolutionary planning proactively reinforces societally desirable developments or minimizes unwelcome developments (Boelens \& De Roo, 2016). We define proactiveness as acting in anticipation of future problems, needs, or changes (Merriam-Webster, 2020), since the essence of urban planning is to help realize better place-based outcomes than would otherwise manifest (Campbell, 2012). Van Assche et al. (2017) suggest that co-evolutionary planning creates goal dependencies which invoke collective action, or create opposition and inspire alternative ways to move forward, whereas Savini et al. (2014) discuss how planning can tweak spontaneous urban development towards shared goals. The need to combine adaptiveness and proactiveness by "doing what is decided and adjusting to what is emerging" (Gerrits \& Teisman, 2012, p. 214) is therefore the challenge of coevolutionary planning. To better understand this challenge in low-growth contexts, we next discuss an evolutionary urban development model devised for shrinking cities.

\section{Co-Evolutionary Urban Planning in Low-Growth Areas}

Schlappa and Neill (2013) have outlined an evolutionary urban development model for shrinking cities, which we apply here to low-growth contexts. The model builds on the adaptive cycle concept (see for example Gunderson \& Holling, 2002) and the subsequent organizational ecocycle concept (Hurst, 1995, 2012; Hurst \& Zimmerman, 1994). The organizational ecocycle explains that human organizations cycle between phases of emergent, rational and constrained action when adapting to their changing 
environment (Figure 1). It is often viewed as beginning at the emergent action phase, where the organization is loosely structured and able to explore opportunities in its environment (Hurst, 1995). During the growth phase, the decision is made to exploit selected opportunities, which makes the organization increasingly structured and efficient (Hurst, 1995). However, this limits the capacity to respond to changes, and the organization may eventually move to the constrained action phase and even to crisis (Hurst, 1995). Schlappa and Neill (2013) suggest that shrinking cities have reached the constrained action phase and are about to enter the back-loop of the ecocycle, portrayed as a dashed line in Figure 1. In this phase, action derived from past opportunities no longer produces the intended effects (Hurst, 1995). Action should instead be taken to develop networks from which new activities can emerge and eventually enable a shift to the emergent action phase (Hurst, 1995; Schlappa \& Neill, 2013). [Figure 1 here]

It should be noted that the ecocycle is not a deterministic prediction of the future, rather a mental model that helps in understanding complex systems (Hurst, 2012). Human and natural systems can go through the cycle in various sequences, except from confusion to conservation (Walker \& Salt, 2006). Likewise while shrinking cities may be perceived to be in crisis (Schlappa \& Neill, 2013), low-growth neighborhoods may, for instance, linger in conservation, shift to creative networking, or return to growth. However, guiding parts of the system towards reorganization from the growth phase can help avoid major crises (Hurst, 2012; Walker \& Salt, 2006). This implies that in low-growth areas, intentional urban development activities could help avert crises and enhance the area's adaptation to contextual changes.

\section{Rational Action in the Front- and Back-Loops of the Ecocycle}

According to Hurst (1995), front- and back-loops of the ecocycle require a different 
understanding regarding rational action, which he defines as 'purposive action' that deals with means-ends relationships. The front-loop corresponds to technical rationality, which assumes the world can be objectively known and, thus, the future is predictable. This rationality starts to develop at the emergent action phase, where the loosely structured organization, guided only by an abstract mission, experiments with cause and effect relationships in its context. This allows the organization's mission to be translated into a concrete strategy that informs operation in the context. The known cause and effect relationships enable planning and thought to precede action, and action becomes an instrument to achieve predefined goals using the most effective means. However, optimizing performance through strategy may lead to long feedback loops between actions and planning, which reduces the capacity to respond to change. (Hurst, 1995.)

In the back-loop, where the context has changed, the cause and effect relationships are unknown and the future is unpredictable (Hurst, 1995). There, goals or means cannot be selected as the organization does not know where it is headed, and action must precede planning. Rational action in the back-loop is therefore not about devising a strategy as a prescription for action but about action that creates contexts for new action and learning. The purpose is to enable a shift from constrained to emergent action, where experimentation with cause and effect relationships is again possible. Hurst (1995) further proposes three activities that can generate new action in the backloop. Managers may guide the organization towards renewal by changing the status quo and making room for new activities. However, the outcomes should be acknowledged as unpredictable, and not treated as inputs to a causal process that will generate expected results. Furthermore, the motivation to act in a constrained context can be generated by a shared mission, which makes action feel intrinsically valuable and, 
hence, does not have to be motivated by a future goal. Finally, the emerging activities can be fostered by providing contexts for learning and experimentation. (Hurst, 1995.)

Schlappa and Neill (2013) suggest associating urban planning in shrinking cities with the back-loop rationality of the organizational ecocycle. Back-loop rationality could be connected to co-evolutionary urban planning too, where adaptation to the initial context, deliberate action to change the context, and the ability to adapt to outcomes are highlighted (Bertolini, 2007; Gerrits \& Teisman, 2012). Bertolini (2007, 2010) suggests that in the face of uncertainty, planning goals and means should be defined for compatibility with various future developments. This could be connected to back-loop activity that aims to change the status quo while accepting various outcomes (Hurst, 1995). The capacities of urban planning to invoke collective action in uncertain contexts (Savini et al., 2014; Van Assche et al., 2017) resonate with the idea of a mission that intrinsically motivates action (Hurst, 1995). Co-evolutionary planners have been referred to as transition managers who create conditions for self-organizing urban development (De Roo, 2012; De Roo \& Boelens, 2016), which is compatible with the idea of managers providing contexts for spontaneous action (Hurst, 1995).

However, we observe that extant conceptualizations of co-evolutionary planning mainly discuss large-scale urban development projects that have faced contextual volatility (see for example, Bertolini, 2010; Gerrits \& Teismann, 2012; Majoor, 2015). Consequently, they often presume an ongoing activity, during which adaptation is needed. We believe that back-loop rationality merits further exploration as the proactive feature of co-evolutionary urban planning in situations where urban planning contributes to the generation of new activities.

A further challenge is that urban planning has traditionally focused on the frontloop of the ecocycle (Partanen, 2018), where selection of planning goals and means 
precedes action. Such a planning approach implies a situation where known causalities are utilized to predict the future and as a prescription for action (De Roo, 2012). In the back-loop, this is not an adequate approach as the cause and effect relationships are unclear. However, we do not suggest equating front-loop rationality in urban planning with the separation of formal and substantive rationality, that is, separating procedures to achieve given ends from ideologies and values related to those ends (Allmendinger, 2002). In urban planning, the intersubjective nature of reality is widely acknowledged, and practices to define planning goals and means in a communicative process have been developed (Allmendinger, 2002). However, De Roo (2012) argues that after moving from planning to implementation, the progress of urban development is often viewed as a logical outcome of selected ends and means, which does not always correspond with the dynamic nature of reality.

\section{Co-Evolutionary Planning in Turku Suburbs}

Our case studies comprise urban development activities in three low-growth suburbs of Turku: Runosmäki, Härkämäki, and Pansio-Perno. In Finland, suburbs were built outside city centers from the 1940s to the 1980s, when urbanization was rapid and new housing was needed. Today, suburbs often face problems related to built environment maintenance lag, declining population, social segregation, and under-utilized public and private services. The suburbs could be said to have gone through the front-loop of the ecocycle, and now need to adapt to a changed context. One suggested means for suburban redevelopment is urban infill, which could bring in new inhabitants and support policy goals related to urban intensification. Due to the Finnish plan-led spatial planning system, cities can advance infill development by designating selected suburbs as strategic infill development areas in their master plans. In addition, cities can utilize 
public land development to deliver policy objectives by conveying publicly-owned land for development (Valtonen et al., 2017).

Yet, infill development has limited applicability in Finnish suburbs. Land ownership is often scattered, and implementation is dependent on existing property owners, a considerable share of whom are actually resident-owned housing companies. While financing major repairs might give housing companies an incentive for property development, challenges related to financial and professional resources, collective decision-making, and prejudices against development might prevent it (Puustinen \& Viitanen, 2015). Redevelopment based on public land development is typically enacted only on city-owned sites, such as those formerly reserved for public services and green areas, providing the development has the approval of residents. Moreover, due to the relatively low value of land and high costs of redevelopment, suburbs are not always attractive for market-based urban development, adding uncertainty to infill development implementation. Infill development could therefore be interpreted as a growthdependent strategy not suitable for all suburbs.

This research employs a multiple case study strategy, suitable for understanding a phenomenon through cases that manifest some common or contrasting characteristics (Stake, 2005; Yin, 2014). We base our case selection on information content expectations, which is a plausible approach for small-sample case studies (Flyvbjerg, 2011). Further, we follow the extreme case logic, suitable for gathering information on unusual cases that can increase understanding of existing theories (Flyvbjerg, 2011). Here, we consider the cases deemed unusual, due to the limited discussion on coevolutionary planning in low-growth contexts. We selected the cases through discussion with City of Turku representatives, where the three areas were identified as low growth from the perspectives of market-led urban development and population growth, and 
their future development was considered uncertain. In addition, Turku's forthcoming master plan anticipates only limited population growth in the areas, even though Runosmäki is identified for potential infill development (Figure 2). [Figure 2 here]

The empirical material comprises fifteen interviews with urban planners and other relevant actors in the case study areas. The interviews were semi-structured and thematic, allowing consideration of contextual features and respondents' subjective opinions during discussion (Yin, 2014). From the City organization, we interviewed six persons from the urban planning department, four from the urban development department, and one from the real estate department. In Pansio-Perno we interviewed a representative of a city-owned public housing company, and in Härkämäki representatives of a local neighborhood association, a local maintenance company, and a consulting firm involved in urban development. The duration of the interviews was 30-120 minutes, and they were conducted between November 2016 and June 2017. We asked the interviewees to describe urban development in the case study areas, and to evaluate whether the low-growth context provided specific opportunities or challenges for urban planning. Another main theme concerned cooperation in urban development between the City, private developers, and local communities. To complement our empirical material and to support source triangulation (Yin, 2014), we analyzed selected planning documents related to cases.

\section{Four Territories of Experience to Recognize Back-Loop Rationality}

To define operationally specific variables to identify back-loop rationality from our empirical material, we utilize the four territories of experience approach, suitable for mapping actions that result from pursuing the organization's own intentions and adjusting to external reality (Torbert, 1999; Torbert et al., 2004; Torbert \& Taylor, 
2008). The approach considers human experience via four cognitively accessible territories which, at the organizational level, are visioning, strategizing, performing, and assessing (Torbert et al., 2004). We suggest the underlying mission motivating action in all ecocycle phases (Hurst, 1995) can be connected to visioning, representing organizational values and motivations (Torbert, 1999). Strategizing entails defining practices and results (Torbert, 1999), which we understand as translating the mission into prescriptions for action based on perceived cause and effect relationships (Hurst, 1995). Performing represents concrete actions in the outside world (Torbert, 1999), motivated either by an explicit strategy or intrinsic values and the willingness to learn (Hurst, 1995). Finally, assessing is the territory where the outcomes of actions are evaluated against reality, resulting in feedback and learning (Torbert, 1999).

In technical rationality, the four territories are accessed sequentially (Torbert \& Taylor, 2008). The motivation to act is derived from visioning, plans regarding action are formulated by strategizing, and implemented by performing. Consequences are then assessed in the outside world, and action, strategy or vision adjusted accordingly. This equates with rational action in the ecocycle front-loop, focusing on the achievement of goals based on known cause and effect relationships (Hurst, 1995). We suggest that back-loop rationality requires accessing the territories of performing and assessing prior to strategizing, to learn about action outcomes, while strategy emerges later in the process (Hurst, 1995). Such action is motivated by visioning, but only in terms of abstract, mutually shared values (Hurst, 1995).

We used the four territories of organizational experience as a priori codes and systematically recognized them from the interviews, following the logic presented in Torbert and Taylor (2008, p. 245). We coded the passages where the interviewees stated purposes for action as visioning, the options, perceptions or strategies for action as 
strategizing, the descriptions of concrete actions that were or could be taken as performing, and the assessment of the planning situation and effects of action as assessing. After identifying the four territories of experience from our empirical material, we organized them as coherent stories to identify in which order they were accessed. Next, we present our analysis in more detail.

\section{Case Runosmäki}

Runosmäki is the second largest suburb of Turku, located along one of its main roads, five kilometers north of the city center. It was built mainly in the 1970s and has approximately 6900 residents (City of Turku, 2018a). The population is ageing, which highlights the need for accessible local services (City of Turku, 2015). Our interviewees framed Runosmäki as a lively residential area, but noted that the number of inhabitants and services were steadily declining. There was a motivation to arrest this development to ensure residents' ongoing and future access to services. The interviewees acknowledged that preserving existing services and functions was not meaningful in all low-growth suburbs. However, Runosmäki's advantageous location intimated a future as an attractive residential area and the demand for services would continue.

Urban development in Runosmäki has been strategized to lean on infill development. The forthcoming master plan denotes Runosmäki as a local center located within the strategic urban intensification zone, and expects a $9.6 \%$ population increase in the Runosmäki-Raunistula area by 2029 (City of Turku, 2018b). The City has plans for a new public transport connection from Runosmäki to the city center, which supports the infill development objectives (City of Turku, 2018a). However, many interviewees noted there was currently little demand for new housing in Runosmäki and considered the master plan's population growth prognosis uncertain. 
“The downward development should somehow be arrested. We've thought about infill development, and in Runosmäki it's certainly more realistic than in some other suburbs. But it's not a silver bullet."

City land ownership and public services development are further reasons for strategizing Runosmäki's development as infill development. While most sites reserved for housing are privately owned (City of Turku, 2010), the City owns several public services sites that could be conveyed for infill development. The City's aim is to relocate Runosmäki's existing public services, such as the library, daycare, and youth services to a new community center building, to produce synergies and enable savings in the maintenance costs of public buildings (City of Turku, 2016). The interviewees highlighted that the main motivation for building the new community center is not to enable infill development, but to answer the local organizations' and residents' need for an indoor community space. In addition, they stated that the community center project could have a wider impact on Runosmäki's development:

"Our aim has been to start something new to show the City still invests in Runosmäki and believes in its future".

The City's urban planning department has devised an infill development plan for Runosmäki. The interviewees favored proactive examination of how potential infill development would affect the area, instead of proceeding incrementally, project by project. The plan identifies selected green areas and sites released by the relocation of public services, as potential locations for infill development. Further, this view was adopted in the community center project plan to demonstrate the income the City could gain by conveying sites for infill development. In addition, the plan identifies infill development potential on private housing companies' sites. The identified potential infill development, enabled by the City's public land development, was considered most 
realistic, even though it was unclear whether there was market demand for new development. In relation to this notion, the interviewees explained that the plan did not necessarily imply implementation: its most important task was to support the planning of public services and actualization of the community center, which could then motivate further development.

"In my opinion, the community center is the most important part of the development plan and hopefully will be implemented. So now we just wait and see."

However, some interviewees considered infill planning an unrealistic approach in an area with uncertain development prospects. They stated that plans should only be made once there were actual projects for which to plan. The City's original idea had been to make development plans for all suburbs, but this was later abandoned because the practice was not considered suitable for areas with uncertain future development prospects.

"I do not believe we can develop suburbs by making comprehensive development plans. The only reason to make them is to determine the development potential.

\section{Identifying Back-Loop Rationality in Runosmäki}

At first, it seems that the four territories of experience were accessed sequentially in Runosmäki, and front-loop rationality, where cause and effect relationships are considered known, was utilized. The underlying vision was to secure the quality of everyday life for the residents and support the development of an advantageously located area. Due to the master plan's population growth prognosis, urban development was strategized as infill development. An infill development plan was made, and the community center project identified as a means for the City to affect implementation by its own performance. Yet when assessing, urban planners were uncertain whether infill 
development would actualize. Therefore, urban planning activities in Runosmäki disappointed some interviewees, who considered the approach unsuitable for an uncertain context.

However, urban planning in Runosmäki exhibits features of back-loop rationality, too, where action is taken without knowing the outcomes. It was assessed that while the infill development plan would probably not be implemented as such, it could generate some kind of urban development in the area. In terms of performing, the City was able to implement the community center project that could send a positive signal regarding the area's development and release locations for infill development, while enhancing residents' everyday life by providing them with new services. Those who held this view considered strategizing Runosmäki's development open-ended, and favored taking action to get things moving. The proactive planning action in Runosmäki could thereby be interpreted as back-loop activity that attempted to change the status quo and make room for emerging activities (Hurst, 1995).

\section{Case Härkämäki}

Härkämäki is a suburb located five-and-a-half kilometers northwest of the city center. It lies in the Pansio-Jyrkkälä area, where the City expects a $1.4 \%$ population decrease by 2029 (City of Turku, 2018a). It was built in the 1970s and 1980s and has approximately 1700 residents (Lehtonen et al., 2010). The land belongs to resident-owned housing companies, aside from the streets, green areas and one site reserved for public services, which are owned by the City (City of Turku, 2010). The area has its own maintenance company, Härkämäen Huolto, with property management responsibilities in all the housing companies, and an active neighborhood association, Härkämäkiseura, that seeks to develop social and economic conditions and environmental quality in the area. 
In Härkämäki, urban development started from within the area itself: housing companies, the maintenance company and the neighborhood association have together explored opportunities for neighborhood development. Their vision is to develop a built environment based on residents' needs. The local actors' interest in urban development originates from the need to affordably repair the buildings in the area. A common challenge in Finnish suburbs is that a building's renovation costs are high compared to the value of its apartments. The local actor coalition therefore initiated an area development strategy, which could motivate all the housing companies to renovate their properties simultaneously and thereby enable savings by combining the projects. The strategy could in addition propose improvements to private and public outdoor spaces. This was considered a meaningful alternative to more traditional urban development strategies, such as infill planning, as it would directly benefit the residents by improving the quality of the environment and existing buildings.

"The starting point is that we have to repair the buildings anyway. And now we should think about how it could improve the area as a whole and how the residents could benefit from it."

The neighborhood association and area maintenance company have a long tradition of fostering cooperation between the housing companies. For instance, the local actors had previously drawn up an environmental improvement plan for the area and sought finance for its implementation. At the time of the interviews, they had introduced the idea of joint building retrofitting to the housing companies and hired a consulting firm to facilitate the planning process. The area development strategy was still a long way from completion, and even the willingness of housing companies to participate in it was uncertain. Interviewees admitted that the outcome could deviate from the initial aspirations: for instance, the housing companies could decide to 
renovate only their own properties, and not to take collective action regarding the development of outdoor spaces.

"In fact, the housing companies are not really talking to each other and only consider their own company's future. But now we have tried to get them to think about the whole neighborhood and that together there could be more to accomplish."

The City has not actively participated in strategizing urban development. The forthcoming master plan defines Härkämäki as a completed residential area, located outside the strategic urban intensification zone (City of Turku, 2018b). Moreover, since development activities are ongoing in Härkämäki, the interviewees stated that the City's active participation is not even needed. However, city representatives have viewed selforganizing urban development as a valuable facet and are willing to support it to foster sustainable development of the neighborhood. The initial urban development idea had originated from discussions between the neighborhood association and the City's urban planning directors, where extant local cooperation was identified as something that could contribute to urban development. In addition, the interviewees noted that substantial building renovations will be needed in other suburbs, too. The City anticipates this will initiate some kind of change in the suburbs and is willing to support property owners in the process. The interviewees assessed that developing suburbs through the co-operation of existing property owners would be difficult in areas where, unlike Härkämäki, there is a lack of active local actors. It was suggested that the City could play a role in facilitating cooperation, given that the local actors were interested. Yet, strategic planning for existing built environment's maintenance was a relatively new perspective for the City.

"In urban development, we must have a continuous dialogue with residents and property owners, so that their property development actions could be linked with the 
City's. But it's kind of a mystical process! Maybe we should just start identifying urban development potentials in our neighborhoods to foster activities that could generate something new."

\section{Identifying Back-Loop Rationality in Härkämäki.}

The vision in Härkämäki was to develop a built environment based on residents' needs, for which the prerequisites were generated by the long-standing performance of local actors. Those actors aimed to turn the vision into a more concrete strategy, even though the outcomes were considered uncertain. The City did not attempt to strategize development but was willing to support emerging activities. The activities of the maintenance company, neighborhood association and the City could therefore be interpreted as generating conditions for new activities to emerge (Hurst, 1995). While the City did not have a major role in Härkämäki’s development, the interviewees assessed that in areas where there is a lack of active local actors, it could do more to generate contextual features for nascent urban development activities. But how to go about this was still taking shape.

\section{Case Pansio-Perno}

Pansio and Perno are two adjacent residential areas, located eight kilometers west of the city center. Like Härkämäki, they lie in the Pansio-Jyrkkälä area, where a 1.4\% population decrease is expected by 2029 (City of Turku, 2018a). The forthcoming master plan defines Pansio-Perno as an area for services and housing, located outside of the strategic urban intensification zone (City of Turku, 2018b). Pansio-Perno's location is isolated, separated from downtown Turku by industrial areas and from the seashore by marine industries and the Finnish Navy base. It had once served as a residential area for marine industry workers and their families: industrial operations started in the $1930 \mathrm{~s}$ 
and the adjacent housing was gradually built up during the period 1940-1980 (Mälkki et al., 2016). Today, the area has approximately 5000 residents, but the connection between the housing area and the industry no longer exists, aside from dockyard seasonal workers (Mälkki et al., 2016). Due to its isolated location, the area has not attracted new functions, residents or visitors, which was considered a threat to its future vitality. Alongside private housing, there is nowadays a great deal of public social housing, and many residents are from minority groups. Together, these features have resulted in social segregation.

Due to these challenges, the City has prioritized Pansio-Perno as a target for socially motivated neighborhood development. The interviewees highlighted a strong political will to address segregation in the area, and city representatives were therefore required to take action. In addition, many interviewees felt the recent prosperity of the nearby marine industry could have a positive impact on the neighborhood. The isolated location and safety requirements of the industry, however, limit urban development opportunities. The City would be willing to convey some publicly-owned sites for redevelopment, but private developers have shown no interest. City representatives found it hard to predict what kind of urban development could take place in the area. They pointed out that market-based development interest in Pansio-Perno could rise quickly, if the marine industries' prosperity continued. However, the City was not able to plan for the area's future, since there was a risk that the plans would not be realized. "We have to constantly monitor (...) that we do not do the wrong things before we can be sure there is demand, but at the same time we have to be ready if it happens."

Instead, urban development activities have been strategized to emphasize the area's current strengths and to develop a positive image. After exploring new solutions in several projects, the City has initiated a neighborhood development model where 
residents, local organizations, property owners and city representatives regularly gather to innovate area development. The idea is to originate development activities that will both benefit the neighborhood and communicate that something positive is occurring. "The essence of this model, in my opinion, is that we do not predetermine how to develop the area but recognize its strengths, weaknesses, opportunities and threats by taking action in it. After identifying these, we'll know better how we could make an impact and which partners we need." The activities include a communication plan to promote an area image, community artwork for an old lighthouse building, a new pedestrian path connecting the area to the seashore, and a service point for residents who have difficulties reaching public services. The city-owned rental housing company has contributed by working together with the residents to plan transformations of its apartments and outdoor spaces, and by developing new modes of affordable housing. In addition, a detailed plan for a new area of detached houses was in preparation to mix the types of housing and attract new inhabitants.

The interviewees assessed that the most important feature of Pansio-Perno was the insight that relying on market-based urban development was not realistic, and that taking the current strengths and needs as the starting point was more appropriate. The main motivation for development activities was to address the social problems by improving current conditions, and perhaps to generate something new in the long run. However, concrete goals still had to be articulated to justify the use of public resources. Consequently, some interviewees viewed the idea that the originated small-scale development activities would generate change in the area as somewhat superficial. In addition, when considering the area's development in relation to the prosperous marine industry, the fact that the City could not make clear future plans was considered challenging. While swift action was needed to improve the neighborhood, the City was 
not in a position to steer the marine industry's development and had to wait for emerging opportunities. To resolve these challenges, one interviewee suggested acknowledging the different time spans of urban development: while some development activities were already possible, others would require more time and changes before their realization.

\section{Identifying Back-Loop Rationality in Pansio-Perno}

The vision was to address social segregation and possibly integrate the growth of the nearby marine industry into urban development. However, the City found it hard to strategize development activities, as there was no idea as to what could be achieved. Instead, action was taken to attend to local needs and develop a positive image by performing small-scale development activities. Urban development activity, therefore, followed back-loop rationality, where action is taken to generate an opportunity to learn what to do next. The deployed urban development model, where the City and local actors gathered to innovate area development, could be interpreted as an attempt to generate a shared mission that motivates action in the constrained situation (Hurst, 1995). However, some concrete goals had to be established to justify the activities. This partially resulted in assessing the small development initiatives as separate projects that would alone have only limited impacts on the area's development.

\section{Results and Discussion}

This research aimed to explore co-evolutionary urban planning in low-growth contexts. Based on the ecocycle model, we suggested that in such contexts, co-evolutionary planning could utilize proactive action that develops context without knowing the final outcome. We observed that in all three case studies action was taken with uncertain outcomes, and identified three activities deployed to generate change. Based on these 
activities, we have located our cases in the back-loop of the organizational ecocycle, as depicted in Figure 3. We have located Runosmäki in the conservation phase, where the City attempted to guide the area towards renewal by making room for new activities. Härkämäki is located in the creative network phase, where the City supported contextual features for the self-organizing activities to be enacted. Pansio-Perno is located in the confusion phase, where the City and local actors attempted to generate a mission that motivates action in a constrained context. However, acting without knowing the outcomes was considered challenging in all our cases. We next discuss three identified challenges in more detail. [Figure 3 here]

\section{The Purpose of Proactiveness is Misunderstood}

The first challenge relates to recognizing back-loop rationality in urban planning. In Runosmäki, those who acknowledged the growth expectations as uncertain stated that one aim of the infill development plan was to generate opportunities. We interpret this as an attempt to guide selected parts of the area towards reorganization during the conservation phase by changing the prevailing situation (Hurst, 1995). However, others viewed uncertain implementation of the plan as a failure. Conceptualizations of strategic action have traditionally focused on causal reasoning, which has resulted in attempts to resolve crises with what has worked in the past (Hurst, 2012). For urban planning, this has resulted in reliance on economic growth in low-growth contexts, which easily proves unrealistic (Schlappa \& Neill, 2013). In Runosmäki, those who deployed causal reasoning presumably associated the urban planning activities with the growth-dependent approach, where urban plans are devised to guide market-based development. From this perspective, selected activities were not suitable for the uncertain situation, as there was nothing yet to guide. However, when viewed through 
back-loop rationality, the purpose was to initiate change and see what would follow.

One reason for not considering urban planning as co-evolutionary in Runosmäki was presumably that the community center represented an investment for the City, and infill development was viewed as a means to finance it. When utilizing public land development, cities often face the two hats dilemma: whether to maximize project capacities to advance societally desirable development, or earn returns from their land development practices (van der Krabben \& Jacobs, 2013). To balance these needs, urban development projects are often combined as packages, where some projects are used to finance others, leading to linear programming of development (Savini et al., 2014). The inability to predict future demand for development has turned actors' attention to initiatives that are not based on interlinked economic arrangements, such as self-developed housing, temporary urban uses, and an overall focus on qualitative spatial features (Savini et al., 2014). We thereby suggest that co-evolutionary urban planning in low-growth areas would require appreciating urban development projects based on their capacity to produce immediate, qualitative values and generate unforeseen opportunities, separated from their capacity to generate revenues.

\section{Resources needed for proactiveness are limited}

The second challenge relates to the limited capabilities of local actors to take action in a constrained context. In Härkämäki, urban planners recognized the need to support contextual features, where self-organizing urban development takes place (see De Roo, 2012). This activity is relevant in the context of limited economic growth, where urban development will most likely focus on maintaining the existing built environment, and be increasingly dependent on property owners, residents and communities (JanssenJansen et al., 2012). Yet existing skills might not match the requirements of the changed 
situation (Hurst \& Zimmerman, 1994). Local actors, such as private housing companies in Finnish suburbs, might have limited financial and professional capabilities to act as property developers (Puustinen \& Viitanen, 2015), let alone plan for long-term area development. Furthermore, while the new task of urban planning in low-growth contexts could be to support urban development that stems from the activities of local communities (Rydin, 2013; Schlappa \& Neill, 2013), it might be challenging to recognize. As Janssen-Jansen et al. (2012) discuss in the context of the Netherlands, strategic urban planning has paid scant attention to developing existing built environment. In Finland, mainstream urban planning mostly considers urban development in terms of formal land-use planning projects, and seldom deals with urban change that stems from the everyday life of urban neighborhoods (Wallin, 2019). Selforganizing urban development calls for planning approaches that follow and support these activities on their own terms (Boonstra \& Boelens, 2011; Boelens \& Coppens, 2015). One approach could be to nurture supportive structures for everyday life in urban neighborhoods, which in the long run may create prerequisites for urban development activities (Wallin, 2019). We suggest that recognizing low-growth contexts as coevolutionary could help in developing urban planning in this direction.

\section{Constrained Situation Produces Fear of Proactiveness}

The third challenge is to accept urban planning as an activity with uncertain outcomes. In Pansio-Perno, the City innovated urban development in cooperation with local organizations and residents. We interpret this as an attempt to create a shared vision which motivates action in a constrained context (Hurst, 1995; Schlappa \& Neill, 2013). However, future uncertainty might produce 'fear of foresight', that is, unwillingness to take action when expectations may not actualize (e Cunha et al., 2006). Regarding 
urban planning, perceived contextual constraints may prevent seeking out opportunities and result in inaction (Forester, 2016). This challenge was visible in Pansio-Perno, where the development activities were considered modest and their capacity to initiate positive change was doubted. However, when the future is uncertain, the purpose of proactive action is learning what to do next, rather than reaching predefined goals (Hurst, 1995). This implies not considering unrealized outcomes of urban development as a failure but an outcome of co-evolution (Kosunen \& Hirvonen-Kantola, 2020).

One major challenge is that urban planning often has high societal impacts and is expected to be reliable and efficient (Bertolini, 2010; Majoor, 2015). In Pansio-Perno, long-term goals had to be articulated to justify the development activities, even though they were intended as open-ended. Recognizing tolerance for error in different planning situations could help overcome this challenge. As Crossan and Hurst (2006) discuss, while all explorative action produces error, defining acceptable levels thereof could help in assessing the associated risks. In low-growth areas, large investments in interlinked projects could carry an intolerable degree of error (Janssen-Jansen et al., 2012), whereas, in supporting independent development initiatives, various outcomes could be welcomed (Boelens \& Coppens, 2015). In addition, external expectations partially define tolerance for error (Crossan \& Hurst, 2006). In urban planning, the expectations of planning participants could be managed (see Hartmann, 2012) by explicitly communicating that urban planning goals should not be understood narrowly in terms of conformity, but also as devices to generate collective action (Beunen et al., 2016).

\section{Conclusions}

In low-growth areas, planning for future growth is considered an inappropriate approach. Our research shows that while planning for future growth may be irrational, 
planning for the future was not. We conclude that applying back-loop rationality to urban planning could enhance its capacities to operate in low-growth contexts.

However, we do not claim that urban development would deterministically follow the ecocycle or that urban planning activities would be contingent on objective reality. Context-dependent planning approaches are selected based on intersubjective perceptions, and urgent matters may require selecting actions that produce predefined outcomes in uncertain contexts (Zuidema, 2016). The rationalities are likely to blend in practice and be employed in parallel, as selecting just one urban planning approach might reduce the capacity to cope with changes (Majoor, 2015). Nevertheless, we propose the ecocycle as a heuristic to identify planning activities for low-growth areas with contextual differences, to be used in urban planning that acknowledges objective, intersubjective and dynamic realities (see De Roo, 2012).

Our research extends the discussion on co-evolutionary urban planning to lowgrowth contexts, by developing the idea presented by Schlappa and Neill (2013) that urban development could be generated gradually in an evolutionary process. Our theoretical contribution is to connect co-evolutionary planning to the rational action needed in the back-loop of the organizational ecocycle, and identify three activities and challenges for proactive co-evolutionary planning in low-growth contexts. We believe our results have practical relevance, too, as they help identify urban planning activities for different contexts. As a methodological contribution, we present the four territories of experience approach as a way to recognize co-evolutionary planning as actions.

Future research could investigate how the three challenges might be resolved. The generalizability of our results is limited by their derivation from a single city, operating in the context of a Finnish plan-led spatial planning system and public land development practice. Research on different planning systems and cultures could reveal 
new insights on co-evolutionary planning in low-growth contexts. A further limitation is that our empirical material focuses on the experiences of planners over a relatively short period of time. Longitudinal research could deliver further insights on co-evolutionary urban planning that aims to develop future contexts.

\section{Acknowledgements}

We thank the interviewees for enabling this research. We are also grateful to the journal editors Jill Grant, Heather Campbell and Mark Scott, and to the two anonymous reviewers for their constructive and insightful comments. We thank Alex Frost for proofreading the article.

\section{Disclosure statement}

No potential conflict of interest was reported by the authors.

\section{Funding}

The lead author has received funding from the Turku Urban Research Programme.

\section{Biographical notes}

Hanna Kosunen is a PhD student at the Oulu School of Architecture, University of Oulu. Her $\mathrm{PhD}$ research project investigates urban planning approaches for low-growth areas. She has been involved in various research projects conducted in cooperation with cities, dealing with integrative urban development, urban regeneration, and energy transition.

Irina Atkova received her D.Sc. (2018) from Oulu Business School, University of Oulu. Her dissertation explains how entrepreneurs create business models to capture opportunities. She has been involved in several research projects, dealing with the development of the Arctic and Barents region, as well as with Finnish software companies as drivers of the digital economy.

Sari Hirvonen-Kantola is a Postdoctoral Researcher at the Oulu School of Architecture, University of Oulu. In her PhD dissertation (2013), she identified five types of integrative landuse planning work, labeled to diverse markets. Subsequently, she has worked with smart cities and municipalities to detect and develop integrative urban design and planning management practices, from the perspective of collaboration in sustainable land-use planning, and business and innovation development. 


\section{References}

Allmendinger, P. (2002). Planning theory. Palgrave.

Bertolini, L. (2007). Evolutionary urban transportation planning: An exploration. Environment and Planning A, 39(8), 1998-2019.

Bertolini, L. (2010). Coping with the irreducible uncertainties of planning: An evolutionary approach. In P. Healey \& J. Hillier (Eds.), The Ashgate research companion to planning theory: Conceptual challenges for spatial planning (pp. 413-424). Ashgate.

Beunen, R., Duineveld, M., \& Van Assche, K. (2016). Evolutionary governance theory and the adaptive capacity of the Dutch planning system. In G. De Roo \& L. Boelens (Eds.), Spatial planning in a complex unpredictable world of change: Towards a proactive co-evolutionary type of planning within the Eurodelta (pp. 98-117). InPlanning.

Boelens, L., \& De Roo, G. (2016). Planning of undefined becoming: First encounters of planners beyond the plan. Planning Theory, 15(1), 42-67.

Boelens, L., \& Coppens, T. (2015). Actor-relational planning in deprived areas: Challenges and opportunities in Luchtbal Antwerpen, Belgium. Planning Practice \& Research, 30(4), 410-423.

Boonstra, B., \& Boelens, L. (2011). Self-organization in urban development: Towards a new perspective on spatial planning. Urban Research \& Practice, 4(2), 99-122.

Campbell, H. (2012). Planning to change the world: Between knowledge and action lies synthesis. Journal of Planning Education and Research, 32(2), 135-146.

City of Turku. (2010). Kaupungin maanomistus [City's land-ownership]. City of Turku, Urban Environment Division. https://www.turku.fi/sites/default/files/atoms/files//2_9_kaupungin_maanomistu s.pdf

City of Turku. (2015). Runosmäen yleissuunnitelma: Yleiskaavan 2029 osaselvitys [Runosmäki general plan: Appendix for Master plan 2029]. Unpublished planning document. City of Turku, Urban Environment Division.

City of Turku. (2016). Runosmäen monitoimitalo: Tarveselvitys [Runosmäki community center: Needs assessment]. City of Turku. http://ah.turku.fi/kh/2017/0424010x/Images/1487562.pdf 
City of Turku. (2018a). Yleiskaava 2029, Kaavaselostus (Luonnos) [Master plan 2029, Plan commentary (Draft)]. City of Turku, Urban Environment Division. https://www.turku.fi/sites/default/files/atoms/files//yleiskaava_2029_luonnos_se lostus_24.8.2018_paiv_9.11.2018.pdf

City of Turku. (2018b). Yleiskaava 2029, Kartta 2/8, Asuminen (Luonnos) [Master plan 2029, Map 2/8, Housing (Draft)]. City of Turku, Urban Environment Division. https://www.turku.fi/sites/default/files/atoms/files//yleiskaava_2029_kartta_2__asuminen_muutettu_25.9.18_kylk_ss_387.pdf

e Cunha, M. P., Palma, P., \& da Costa, N. G. (2006). Fear of foresight: Knowledge and ignorance in organizational foresight. Futures, 38(8), 942-955.

Crossan, M. M., \& Hurst, D. K. (2006). Strategic renewal as improvisation: Reconciling the tension between exploration and exploitation. In J. A. C. Baum, S. D. Dobrev \& A. Van Witteloostuijn (Eds.), Ecology and Strategy: Vol. 23. Advances in Strategic Management (pp. 273-298). Emerald.

Davoudi, S. (2012). Resilience: A bridging concept or a dead end? Planning Theory and Practice, 13(2), 299-307.

De Roo, G. (2012). Spatial planning, complexity and a world 'out of equilibrium':

Outline of a non-linear approach to planning. In G. De Roo, J. Hillier \& J. van Wezemael (Eds.), Complexity and planning: Systems, assemblages and simulations (pp. 129-165). Ashgate.

De Roo, G., \& Boelens, L. (Eds.). (2016). Spatial planning in a complex unpredictable world of change: Towards a proactive co-evolutionary type of planning within the Eurodelta. InPlanning.

Ferreira, A., Ribeiro-Santos, J., \& Breda-Vázquez, I. (2020). Transcending dilemmas in urban policy-making: Envisioning versus adapting, growing versus stabilizing. Planning Theory and Practice, 21(1), 76-93.

Flyvbjerg, B. (2011). Case study. In N. K. Denzin \& Y. S. Lincoln (Eds.), The Sage handbook of qualitative research (4th ed., pp. 301-316). Sage.

Forester, J. (2016). Daunting or inviting: "Context" as your working theory of practice [Editorial]. Planning Theory and Practice, 17(2), 169-172.

Gerrits, L., \& Teisman, G. (2012). Coevolutionary planning processes. In G. De Roo, J. Hillier \& J. van Wezemael (Eds.), Complexity and planning: Systems, assemblages and simulations (pp. 199-219). Ashgate. 
Gunderson, L. H., \& Holling, C. S. (2002). Panarchy: Understanding transformations in human and natural systems. Island Press.

Hartmann, T. (2012). Wicked problems and clumsy solutions: Planning as expectation management. Planning Theory, 11(3), 242-256.

Hurst, D. K. (2012). The new ecology of leadership: Business mastery in a chaotic world. Columbia University Press.

Hurst, D. K. (1995). Crisis and renewal: Meeting the challenge of organizational change. Harvard Business School Press.

Hurst, D. K., \& Zimmerman, B. J. (1994). From life cycle to ecocycle: A new perspective on the growth, maturity, destruction, and renewal of complex systems. Journal of Management Inquiry, 3(4), 339-354.

Janssen-Jansen, L. B., Lloyd, G., Peel, D., \& van der Krabben, E. (2012). Planning in an environment without growth (Invited essay for the Raad voor de leefomgeving en infrastructuur (Rli), the Netherlands). Raad voor de leefomgeving en infrastructuur. https://pure.uva.nl/ws/files/1862980/117305_essay_rli_planning_in_an_environ ment_without_growth.pdf

Kosunen, H., \& Hirvonen-Kantola, S. (2020). Fatalism in co-evolutionary urban planning: Experiences from infill planning in Finland. Planning Practice \& Research, 35(3), 251-266.

Lehtonen, H., Männistö, I., Oförsagd, M., \& Åland, J. (2010). Härkämäki: Tulevaisuuden lähiö jo huomenna (Yhteisöhanke 10. Loppuraportti 15.11.2010) [Härkämäki: Future suburb already tomorrow (Community project 10. Final report 15.11.2010)]. Härkämäkiseura r.y. https://docplayer.fi/38174742Harkamaki-tulevaisuuden-lahio-jo-huomenna.html

Majoor, S. (2015). Resilient practices: A paradox-oriented approach for large-scale development projects. Town Planning Review, 86(3), 257-277.

Merriam-Webster. (2020, June 27). Proactive. Merriam-Webster. https://www.merriamwebster.com/dictionary/proactive

Mälkki, M., Norvasuo, M., \& Hirvonen, J. (2016). Olosuhteita ja hyödynnettäviä voimavaroja: Pyöreän pöydän malli Pansio-Pernon kehittämisessä [Circumstances and utilizable resources: Round table model in Pansio-Perno's 
development]. In M. Norvasuo (ed.), Lähiö ja kaupunki: Asuinalueen rajat muutoksessa (Aalto TT 3/2016, pp. 61-99). Aalto University.

Partanen, J. (2018). 'Don't fix it if it ain't broke': Encounters with planning for complex self-organizing cities [Doctoral dissertation, Tampere University of Technology]. Tampere University Open Institutional Repository. http://urn.fi/URN:ISBN:978-952-15-4073-8

Puustinen, T., \& Viitanen, K. (2015). Infill development on collectively owned residential properties: Understanding the decision-making process - Case studies in Helsinki. Housing, Theory and Society, 32(4), 472-498.

Rydin, Y. (2013). The future of planning: Beyond growth dependence. Policy press.

Savini, F., Salet, W., \& Majoor, S. (2014). Dilemmas of planning: Intervention, regulation, and investment. Planning Theory, 14(3), 296-315.

Schlappa, H. (2016). If not growth what then? Re-thinking the strategy process for shrinking cities. In W. J. V. Neill \& H. Schlappa (Eds.), Future Directions for the European Shrinking City (pp. 180-191). Taylor \& Francis.

Schlappa, H., \& Neill, W. J. V. (2013). From crisis to choice: Re-imagining the future in shrinking cities. URBACT. https://urbact.eu/sites/default/files/import/general_library/19765_Urbact_WS1_ SHRINKING_low_FINAL.pdf

Stake, R. E. (2005). Qualitative case studies. In N. K. Denzin \& Y. S. Lincoln (Eds.), The Sage handbook of qualitative research (3rd ed., pp. 443-466). Sage.

Torbert, B., \& Associates. (2004). Action inquiry: The secret of timely and transforming leadership. Berrett-Koehler.

Torbert, W. R., \& Taylor, S. S. (2008). Action inquiry: Interweaving multiple qualities of attention for timely action. In P. Reason \& H. Bradbury (Eds.), The Sage handbook of action research: Participative inquiry and practice (2nd ed., pp. 238-251). Sage.

Torbert, W. R. (1999). The distinctive questions that Developmental Action Inquiry asks. Management Learning, 30(2), 189-206.

Valtonen, E., Falkenbach, H., \& van der Krabben, E. (2017). Risk management in public land development projects: Comparative case study in Finland, and the Netherlands. Land Use Policy, 62(1), 246-257. 
van der Krabben, E., \& Jacobs, H. M. (2013). Public land development as a strategic tool for redevelopment: Reflections on the Dutch experience. Land Use Policy, 30(1), 774-783.

Van Assche, K., Beunen, R., \& Duineveld, M. (2017). Co-evolutionary planning theory: Evolutionary governance theory and its relatives. In M. Gunder, A. Madanipour \& V. Watson (Eds.), The Routledge handbook of planning theory (pp. 221-234). Routledge.

Walker, B. H., \& Salt, D. (2006). Resilience thinking: Sustaining ecosystems and people in a changing world. Island Press.

Wallin, S. (2019). Managing urban complexity: Participatory planning, selforganization and co-production of urban space [Doctoral dissertation, Aalto University]. Aaltodoc Publication Archive. http://urn.fi/URN:ISBN:978-952-60$8702-3$

Yin, R. K. (2014). Case study research: Design and methods (5th ed.). Sage.

Zuidema, C. (2016). Decentralization in environmental governance: A post-contingency approach. Routledge. 


\section{Figures}

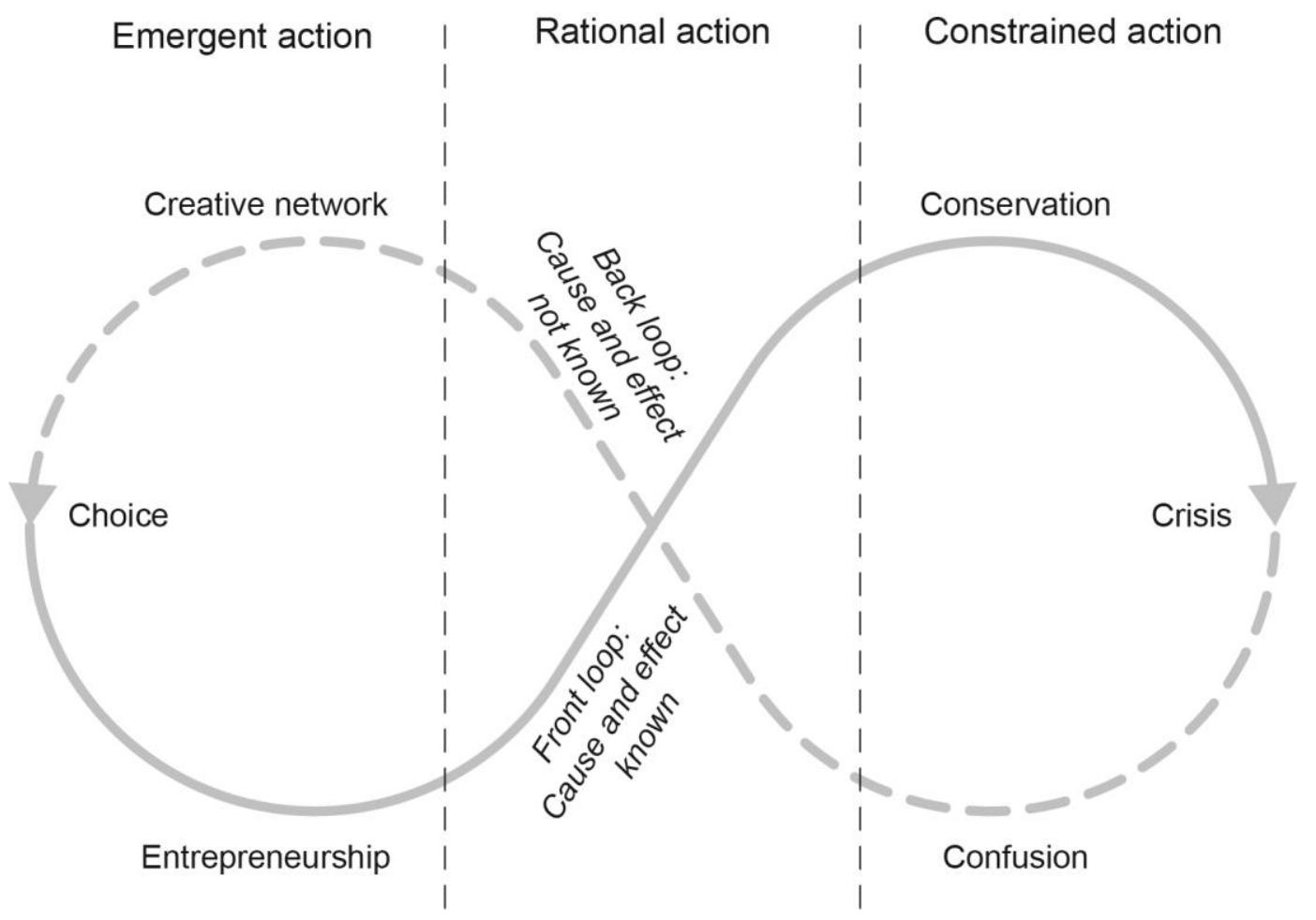

Figure 1. Organizational ecocycle. (Adapted and reprinted with permission from Harvard Business Publishing. From "Crisis \& Renewal: Meeting the Challenge of Organizational Change” by David K. Hurst. Harvard Business Review Press, 1995. Copyright 1995, 2002 by David K. Hurst; all rights reserved.) 


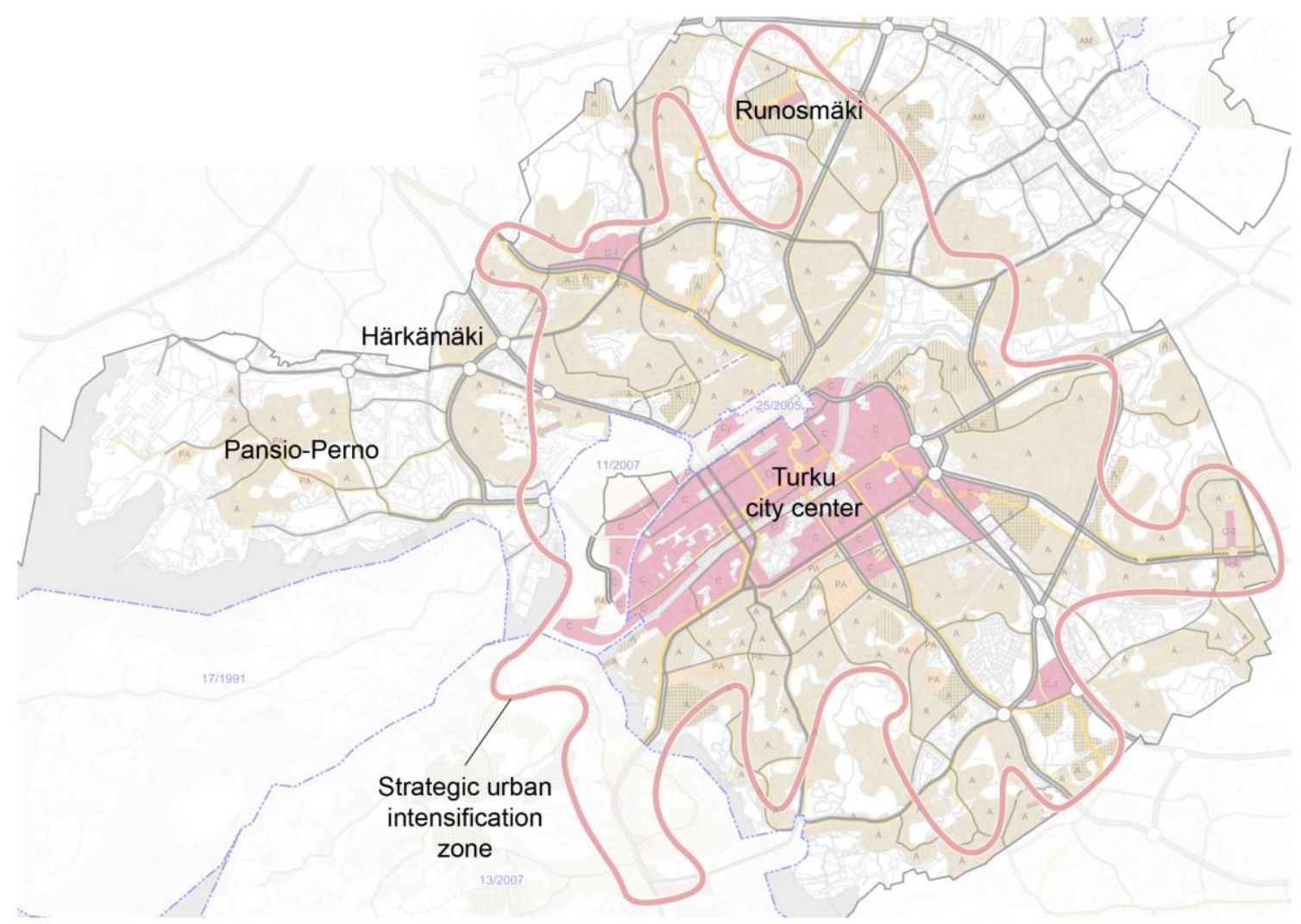

Figure 2. Case study areas in relation to master plan objectives. (Adapted and reprinted with permission from City of Turku. Adapted from "Yleiskaava 2029, Kartta 2/8, Asuminen [Master plan 2029, Map 2/8, Housing]" by City of Turku, Urban Environment Division, 2018, https://www.turku.fi/sites/default/files/atoms/files//yleiskaava_2029_kartta_2__asuminen_muutettu_25.9.18_kylk_ss_387.pdf. Copyright 2020 by Turun Kaupunkiympäristötoimiala.) 


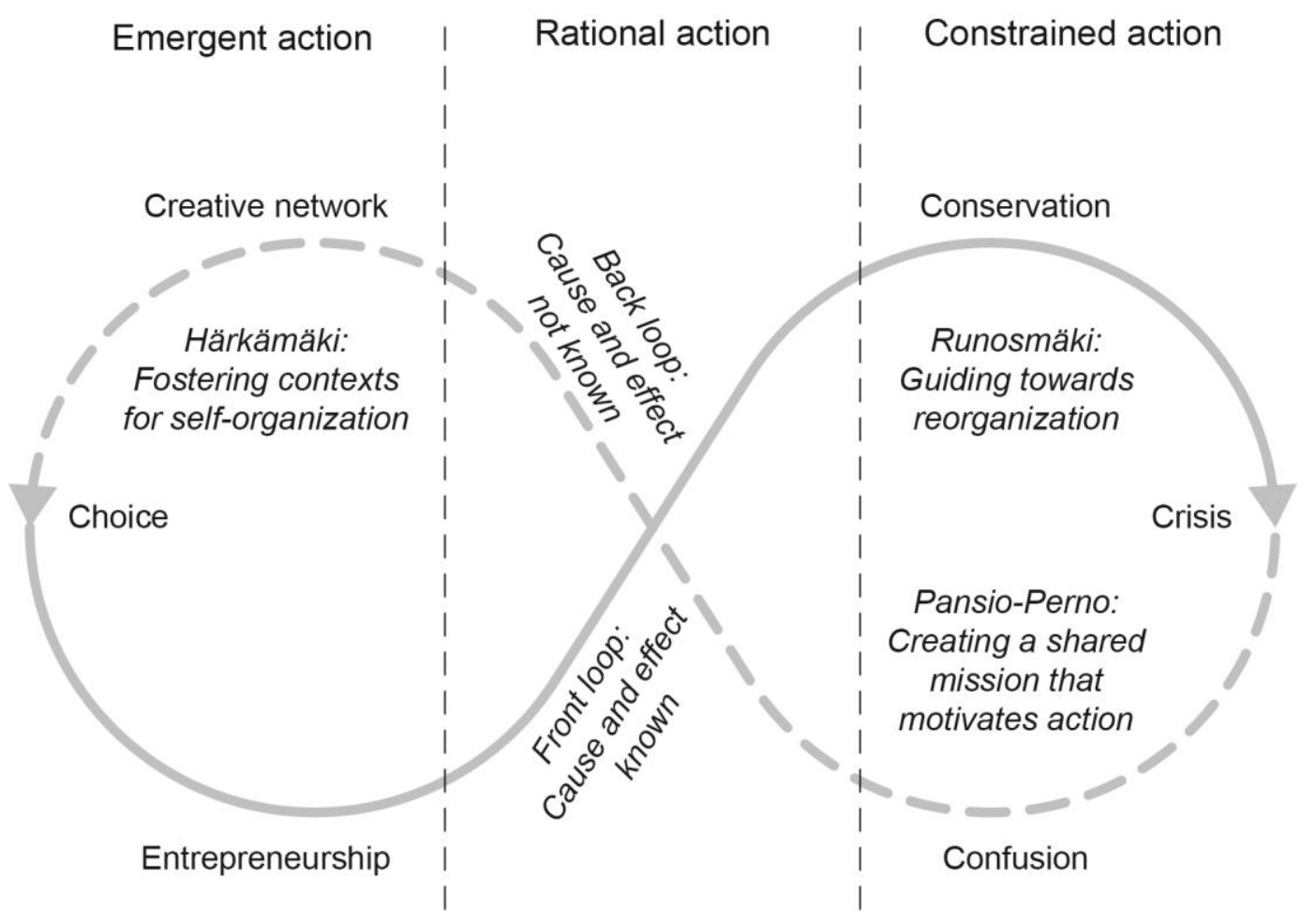

Figure 3. Urban planning activities in the back-loop. (Adapted and reprinted with permission from Harvard Business Publishing. From "Crisis \& Renewal: Meeting the Challenge of Organizational Change" by David K. Hurst. Harvard Business Review Press, 1995. Copyright 1995, 2002 by David K. Hurst; all rights reserved.) 